\title{
Optimasi Desain Ban Tanpa Udara (Non Pneumatic Tire) Dengan Struktur Hexagonal Honeycombs Menggunakan Response Surface Method (RSM)
}

\author{
Design Optimization of Non Pneumatic Tire With Hexagonal Honeycombs Structure \\ Using Response Surface Method (RSM)
}

\author{
Farit Hendro Wibowo ${ }^{1 *}$, Moch. Agus Choiron², Anindito Purnowidodo ${ }^{3}$ \\ ${ }^{1,2,3}$ Mechanical Engineering Department, Universitas Brawijaya
}

\begin{tabular}{l}
\hline \hline ARTICLE INFO \\
\hline Article history: \\
DOI: \\
10.30595/pspfs.v1i.141 \\
Submitted: \\
June 28, 2021 \\
Accepted: \\
July 14, 2021 \\
Published: \\
Oct 31, 2021 \\
\hline Keywords: \\
Airless Tire, Hexagonal \\
Honeycombs Spokes, Military \\
Tactical Vehicle, Non- \\
pneumatic tires \\
\hline
\end{tabular}

\begin{abstract}
Non-Pneumatic Tires (NPT) are tires that do not use compressed air like other tires. In this paper, the optimal design obtained is based on the static and explicit dynamic behavior of the NPT construction, which has hexagonal honeycomb spokes. The hexagonal honeycomb type NPT component consists of the hub wheel, outer ring, spokes, and tread. The honeycomb model is made differently based on tread thickness $(20 \mathrm{~mm}, 25 \mathrm{~mm}, 30 \mathrm{~mm})$, outer ring thickness $(0.25 \mathrm{~mm}, 0.5 \mathrm{~mm}, 0.75$ $\mathrm{mm})$, spokes thickness $(3 \mathrm{~mm}, 5 \mathrm{~mm}, 7 \mathrm{~mm})$, and the number of spokes holes (12, 13, 14). Based on the simulation results of Ansys and Minitab, the recommended optimal design is $20 \mathrm{~mm}$ tread thickness, $3.2 \mathrm{~mm}$ spokes thickness, $0.25 \mathrm{~mm}$ outer thickness, and the number of holes 12 pieces.
\end{abstract}

This work is licensed under a Creative Commons Attribution 4.0 International License.

\section{Corresponding Author:}

Farit Hendro Wibowo

Mechanical Engineering Department, Universitas Brawijaya

J1. Veteran, Ketawanggede, Kec. Lowokwaru, Kota Malang, Jawa Timur 65145

Email: semnaslppmump2017@gmail.com

\section{PENDAHULUAN}

Ban tanpa udara (Non Pneumatic Tire) merupakan ban yang tidak menggunakan bantuan udara bertekanan seperti ban pada umumnya. Ban ini biasanya digunakan pada kendaraan-kendaraan yang ringan seperti kendaraan pemotong rumput, kendaraan golf, serta juga biasa digunakan pada kendaraan alat berat seperti pada excavator, wheel loader, buldoser dan lain sebagainya dimana kendaraan alat berat tersebut beroperasi pada medan-medan yang berat dengan resiko kerusakan pada ban yang sangat tinggi.

Ban tanpa udara (Non Pneumatic Tire) bisa digunakan sebagai alternatif pengganti ban pneumatik karena mempunyai keunggulan seperti tidak menggunakan run-flat, tidak memerlukan tekanan udara dan mempunyai tahanan gelinding yang rendah dibandingkan dengan ban pneumatik konvensional [1-2]. Tipikal dari NPT biasanya terdiri dari hub, jari-jari fleksibel, cincin geser dan tapak. Tapak biasanya terbuat dari karet sintetis dan cincin geser adalah struktur komposit yang terdiri dari pita geser dengan dua tulangan melingkar. Jari-jari NPT membutuhkan kombinasi kekakuan dan ketahanan di bawah beban kompresi tegangan yang berulang sehingga pemilihan material dan desain struktural sangat menentukan [3-4]. Tipe jari-jari fleksibel pada NPT biasanya 
berbentuk sarang lebah (hexagonal honeycombs), dimana struktur sel sarang lebah dapat dimodifikasi dengan menyesuaikan sudut sel, ketebalan dan panjang dinding untuk menghasilkan kekakuan dan kekuatan material yang dipakai[5-6].

Beberapa penelitian tentang NPT juga pernah dilakukan, bertujuan untuk mendapatkan desain struktural dan optimalisasi pada NPT. Ju dkk. [8] meneliti model elemen hingga pada NPT dengan struktur sarang lebah sebagai unit geser untuk mengetahui berapa besar tekanan kontak ban dalam satu dimensi. Penambahan hexagonal honeycomb shear band yang dilengkapi dengan sudut sel yang lebih tinggi bertujuan untuk memberikan tekanan kontak yang lebih rendah di sepanjang bidang kontak. Kim dkk. [9] mempelajari tentang besar tekanan yang terjadi pada NPT dengan tipe hexagonal honeycomb akibat beban impak vertical dengan kontak statis. Didapatkan bahwa tekanan impak NPT lebih rendah daripada ban pneumatik konvensional karena kekakuan lateral yang tinggi dari konstruksi spokes NPT. Ju dkk. [10] membandingkan dua jenis NPT dengan tipe hexagonal honeycomb. Dapat dilihat bahwa hexagonal honeycomb memiliki tekanan dan bobot lokal yang rendah.

Jaehyung Ju dkk. [11] konstruksi sarang lebah (honeycombs) merupakan konstruksi yang banyak digunakan dalam berbagai macam aplikasi, dikarenakan konstruksi sarang lebah (honeycombs) memiliki rasio kekuatan yang tinggi dalam menerima beban berat dan cenderung mempunyai sifat struktur yang dominan lentur. Jin dkk. [12] untuk meningkatkan efektifitas bidang, kekuatan luluh, dan kekuatan tekuk pada konstruksi sarang lebah (honeycombs) telah diteliti dalam beberapa jenis tipe bentuk konstruksi sarang lebah (honeycombs) yang berbeda, yaitu tipe bentuk persegi, heksagonal, segitiga, campuran antara segitiga dan kotak, dan diamond. Untuk tipe segitiga dan diamond bagus digunakan untuk desain struktur yang mempunyai modulus tinggi, sedangkan untuk tipe hexagonal dan persegi diketahui mempunyai struktur yang lentur sehingga bagus digunakan untuk desain struktur yang fleksibel dan mampu untuk menerima beban aksial maupun beban geser.

Konstruksi honeycomb spokes pada ban tanpa udara harus mempunyai sifat kaku dan tahan terhadap tekanan, dimana secara umum kekakuan dan ketahanan suatu material merupakan persyaratan yang saling bertolak belakang apabila suatu material tersebut mempunyai tingkat modulus bahan yang tinggi, sehingga tingkat regangan elastisitasnya rendah, demikian juga sebaliknya apabila modulus bahannya rendah maka tingkat regangan elastisitasnya akan tinggi. Sehingga harus diperhitungkan bagaimana cara merancang suatu material yang memiliki kekakuan dan ketahanan yang tinggi. Itu semua tidak mudah dikarenakan sangat sulit mendapatkan suatu material yang memenuhi sifat seperti yang dijelaskan diatas, solusinya adalah harus mengoptimalkan desain ban tanpa udara dengan material yang digunakan sehingga sifat dari ban tanpa udara yang diinginkan dapat tercapai.

Berdasarkan permasalahan yang ada pada ban tanpa udara, kami sebagai peneliti tertarik untuk meneliti tentang optimasi desain ban tanpa udara (Non Pneumatic Tire) sehingga akan mendapatkan suatu ban tanpa udara yang mampu untuk digunakan pada kendaraan yang mempunyai kemampuan minimal sama dengan ban yang menggunakan udara bertekanan, oleh karena itu kami akan mengangkat judul penelitian tesis yaitu "Optimasi Design Ban Tanpa Udara (non pneumatic tire) dengan Struktur Hexagonal Honeycombs menggunakan Response Surface Method (RSM)". Dalam penelitian ini kami fokus pada tipe jari-jari fleksibel berbentuk hexagonal honeycomb, dimana dalam proses analisisnya kita akan menggunakan simulasi Ansys Workbench dan minitab.

\section{METODE PENELITIAN}

Pada penelitian ini, dilakukan menggunakan metode simulasi menggunakan aplikasi minitab untuk mencari data statistiknya kemudian untuk simulasi static dan explicit dynamic menggunakan aplikasi Ansys Workbench, kemudian untuk hasil yang didapatkan akan dianalisa secara manual. adapun spesifikasi model NPT ditunjukkan pada Tabel 1 .

Tabel 1. Parameter Desain NPT

\begin{tabular}{|c|c|c|c|c|c|c|c|c|c|c|c|c|}
\hline & \multirow[t]{2}{*}{$\begin{array}{c}\mathrm{t} \\
(\mathrm{mm})\end{array}$} & \multirow[t]{2}{*}{$\alpha\left(^{\circ}\right)$} & \multicolumn{2}{|c|}{$\mathrm{h}(\mathrm{mm})$} & \multicolumn{4}{|c|}{$\mathrm{L}(\mathrm{mm})$} & \multicolumn{4}{|c|}{$\mathrm{R}(\mathrm{mm})$} \\
\hline & & & h1 & 66,75 & L1 & 35,19 & L6 & 34,49 & R1 & 327,00 & R6 & 216,82 \\
\hline \multirow{4}{*}{1} & \multirow{4}{*}{3} & \multirow{4}{*}{27,69} & h2 & 66,75 & L2 & 36,04 & L7 & 42,23 & $\mathrm{R} 2$ & 260,25 & R7 & 219,82 \\
\hline & & & h3 & 30,29 & L3 & 40,53 & L8 & 26,33 & R3 & 257,25 & R8 & 293,71 \\
\hline & & & h4 & 73,89 & L4 & 27,84 & & & $\mathrm{R} 4$ & 190,50 & R9 & 296,71 \\
\hline & & & h5 & 26,32 & L5 & 33,68 & & & R5 & 190,50 & R10 & 327,00 \\
\hline \multirow{4}{*}{2} & \multirow{4}{*}{5} & \multirow{4}{*}{27,69} & h1 & 63,75 & L1 & 33,00 & L6 & 32,28 & $\mathrm{R} 1$ & 325,00 & R6 & 215,82 \\
\hline & & & h2 & 63,75 & L2 & 35,00 & L7 & 42,19 & $\mathrm{R} 2$ & 261,25 & R7 & 220,82 \\
\hline & & & h3 & 27,29 & L3 & 39,37 & L8 & 23,32 & R3 & 256,25 & $\mathrm{R} 8$ & 292,71 \\
\hline & & & h4 & 71,89 & L4 & 28,83 & & & R4 & 192,50 & R9 & 297,71 \\
\hline
\end{tabular}

Proceedings homepage: $\underline{\text { https://conferenceproceedings.ump.ac.id/index.php/pspfs/issue/view/8 }}$ 


\begin{tabular}{|c|c|c|c|c|c|c|c|c|c|c|c|c|}
\hline \multirow{6}{*}{3} & & & h5 & 23,32 & L5 & 30,46 & & & R5 & 192,50 & R10 & 325,00 \\
\hline & & & h1 & 60,00 & L1 & 30,00 & L6 & 30,00 & $\mathrm{R} 1$ & 330,00 & R6 & 210,00 \\
\hline & & & $\mathrm{h} 2$ & 60,00 & L2 & 30,00 & L7 & 45,00 & $\mathrm{R} 2$ & 255,00 & R7 & 225,00 \\
\hline & 7 & 27,69 & h3 & 30,00 & L3 & 45,00 & L8 & 15,00 & R3 & 255,00 & $\mathrm{R} 8$ & 285,00 \\
\hline & & & h4 & 75,00 & L4 & 30,00 & & & $\mathrm{R} 4$ & 195,00 & R9 & 300,00 \\
\hline & & & h5 & 15,00 & L5 & 30,00 & & & R5 & 195,00 & R10 & 330,00 \\
\hline
\end{tabular}
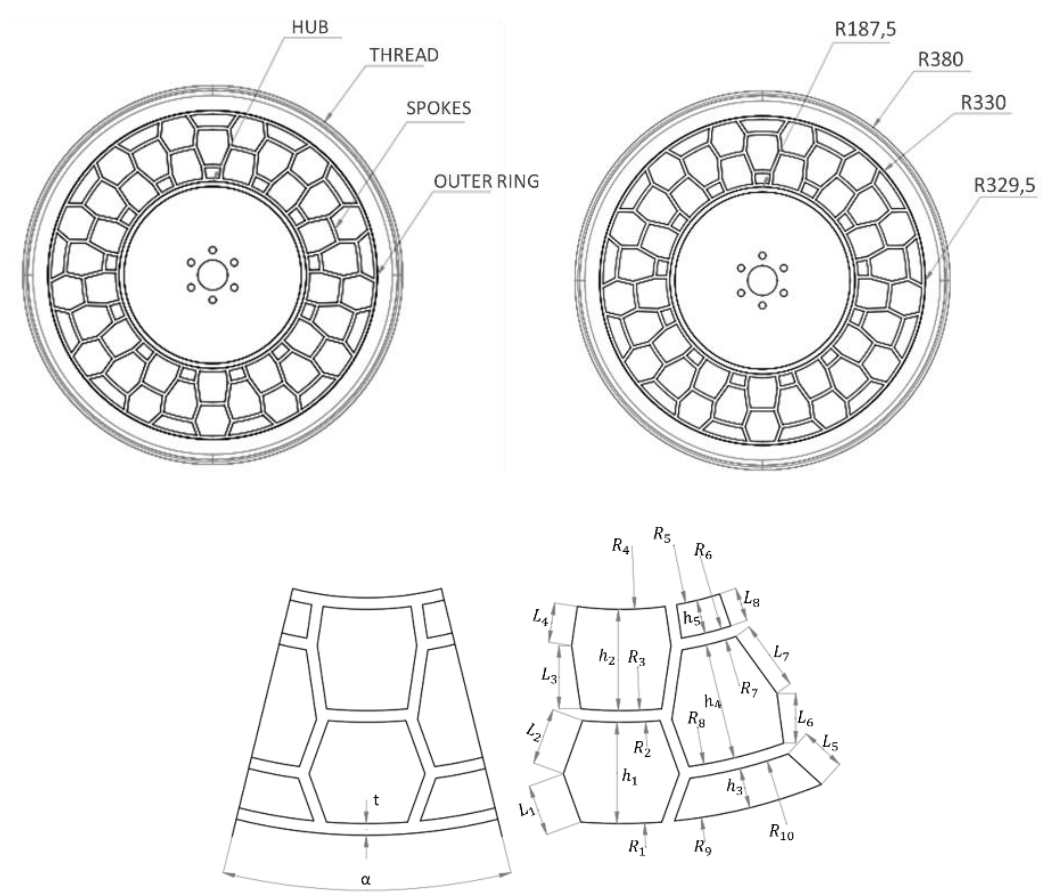

Gambar 1. Model Geometri

Gambar 1 menunjukkan ban tanpa udara dengan tipe sarang lebah heksagonal yang terdiri dari roda hub, lingkar luar, jari-jari, dan tapak. Hub roda terbuat dari Aluminium Alloy (7075-T6) dengan densitas $=2800 \mathrm{~kg} / \mathrm{m} 3$, Modulus Elastisitas $(E)=72 \mathrm{GPa}$, dan Poisson rasio $(\mathrm{v})=0,33$. Lingkar luar terbuat dari baja berkekuatan tinggi ANSI 4340 dengan densitas $=7800 \mathrm{~kg} / \mathrm{m} 3, \mathrm{E}=210 \mathrm{GPa}$, dan Poisson rasio $=0,29$. Ketebalan cincin luar adalah $0,5 \mathrm{~mm}$. Jari-jari sarang lebah heksagonal terbuat dari bahan Poliuretan dengan densitas $=1200 \mathrm{~kg} / \mathrm{m} 3, \mathrm{E}=32$ $\mathrm{MPa}$, dan Poisson rasio $=0,49$. Ketebalan jari-jari bervariasi dengan $3 \mathrm{~mm}, 5 \mathrm{~mm}$ dan $7 \mathrm{~mm}$. Tapak terbuat dari karet alam dengan densitas $=1043 \mathrm{~kg} / \mathrm{m} 3, \mathrm{E}=11,9 \mathrm{MPa}$, dan Poisson rasio $=0,49$. Ketebalan tapak divariasikan dengan $20 \mathrm{~mm}$ dan $30 \mathrm{~mm}$. Untuk parameter penelitian terdiri dari empat item yaitu tebal tapak, tebal spokes, tebal outering dan jumlah lubang spokes, dimana masing-masing parameter akan dibedakan berdasarkan dimensinya seperti terlihat pada table 2 , setelah itu akan dibuat data statistic menggunakan minitab seperti pada table 3, kemudian parameter penelitian kita masukkan kedalam data statistic seperti pada table 4, dan dibuat desain ban tanpa udara dengan dimensi seperti pada data statistic, kemudian dilakukan simulasi statis dan explicit dynamic menggunakan Ansys.

Tabel 2. Parameter Penelitian

\begin{tabular}{clccc}
\hline \multirow{2}{*}{ NO } & \multicolumn{1}{c}{ Parameter } & Low Level & Medium & High \\
\cline { 2 - 5 } & & -1 & 0 & 1 \\
A & Tebal Tapak [mm] & 20 & 25 & 30 \\
B & Tebal spokes $[\mathrm{mm}]$ & 3 & 5 & 7 \\
$\mathrm{C}$ & Tebal Outer Face $[\mathrm{mm}]$ & 0,25 & 0,5 & 0,75 \\
$\mathrm{D}$ & Jumlah Lubang & 12 & 13 & 14 \\
\hline
\end{tabular}


Tabel 3. Desain Statistik Minitab

\begin{tabular}{ccccc}
\hline NO & A & B & C & D \\
\hline 1 & 0 & 0 & 0 & 0 \\
2 & -1 & 0 & 0 & 1 \\
3 & 0 & -1 & -1 & 0 \\
4 & -1 & 0 & 0 & -1 \\
5 & 0 & -1 & 0 & 1 \\
6 & 1 & 0 & 0 & -1 \\
7 & 0 & 0 & 0 & 0 \\
8 & 0 & 1 & -1 & 0 \\
9 & -1 & 0 & -1 & 0 \\
10 & 1 & 0 & -1 & 0 \\
11 & 0 & -1 & 0 & -1 \\
12 & 1 & 0 & 1 & 0 \\
13 & 0 & -1 & 1 & 0 \\
14 & -1 & -1 & 0 & 0 \\
15 & 0 & 0 & -1 & 1 \\
16 & 0 & 1 & 0 & -1 \\
17 & 1 & -1 & 0 & 0 \\
18 & 0 & 0 & 1 & 1 \\
19 & -1 & 1 & 0 & 0 \\
20 & 0 & 0 & 0 & 0 \\
21 & 1 & 0 & 0 & 1 \\
22 & -1 & 0 & 1 & 0 \\
23 & 0 & 0 & -1 & -1 \\
24 & 0 & 1 & 1 & 0 \\
25 & 0 & 0 & 1 & -1 \\
26 & 0 & 1 & 0 & 1 \\
27 & 1 & 1 & 0 & 0 \\
\hline & & & &
\end{tabular}

Tabel 4. Parameter Desain

\begin{tabular}{ccccc}
\hline NO & $\begin{array}{c}\text { A } \\
{[\mathrm{mm}]}\end{array}$ & $\begin{array}{c}\text { B } \\
{[\mathrm{mm}]}\end{array}$ & $\begin{array}{c}\mathrm{C} \\
{[\mathrm{mm}]}\end{array}$ & $\begin{array}{c}\text { D } \\
{[\text { Buah }]}\end{array}$ \\
\hline 1 & 25 & 5 & 0,5 & 13 \\
2 & 20 & 5 & 0,5 & 14 \\
3 & 25 & 3 & 0,25 & 13 \\
4 & 20 & 5 & 0,5 & 12 \\
5 & 25 & 3 & 0,5 & 14 \\
6 & 30 & 5 & 0,5 & 12 \\
7 & 25 & 5 & 0,5 & 13 \\
8 & 25 & 7 & 0,25 & 13 \\
9 & 20 & 5 & 0,25 & 13 \\
10 & 30 & 5 & 0,25 & 13 \\
11 & 25 & 3 & 0,5 & 12 \\
12 & 30 & 5 & 0,75 & 13 \\
13 & 25 & 3 & 0,75 & 13 \\
14 & 20 & 3 & 0,5 & 13 \\
15 & 25 & 5 & 0,25 & 14 \\
16 & 25 & 7 & 0,5 & 12 \\
17 & 30 & 3 & 0,5 & 13 \\
18 & 25 & 5 & 0,75 & 14 \\
19 & 20 & 7 & 0,5 & 13 \\
20 & 25 & 5 & 0,5 & 13 \\
21 & 30 & 5 & 0,5 & 14 \\
22 & 20 & 5 & 0,75 & 13 \\
23 & 25 & 5 & 0,25 & 12 \\
24 & 25 & 7 & 0,75 & 13 \\
25 & 25 & 5 & 0,75 & 14 \\
\hline & & & &
\end{tabular}




\begin{tabular}{lllll}
\hline 26 & 25 & 7 & 0,5 & 14 \\
27 & 30 & 7 & 0,5 & 13 \\
\hline
\end{tabular}

Meshing dilakukan secara manual dengan ukuran elemen $3 \mathrm{~mm}, 5 \mathrm{~mm}, 7 \mathrm{~mm}$ yang merupakan ukuran jarijari heksagonal honeycomb. Jumlah elemen yang didapatkan dengan menggunakan metode segiempat sebanyak 37445 elemen, serta jumlah node 215821. Beban yang dikenakan pada ban tanpa udara yaitu beban maksimum kendaraan sebesar $3000 \mathrm{~kg}$, sehingga setiap roda menerima berat $750 \mathrm{~kg}$ atau $7500 \mathrm{~N}$. Gambar 2 dan 3 menunjukkan kondisi batas statis dan dinamis model NPT.

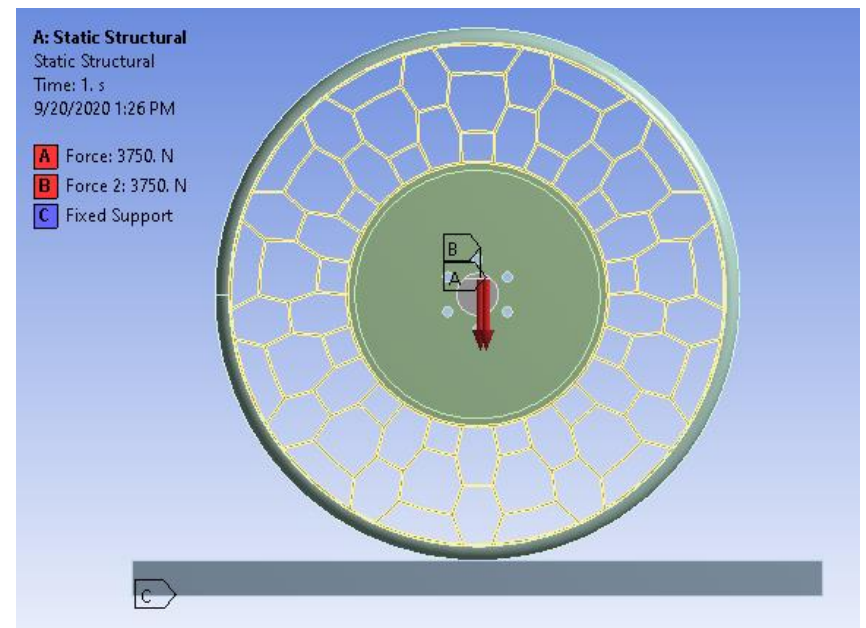

Gambar 2. Boundary Condition pada kondisi Statis
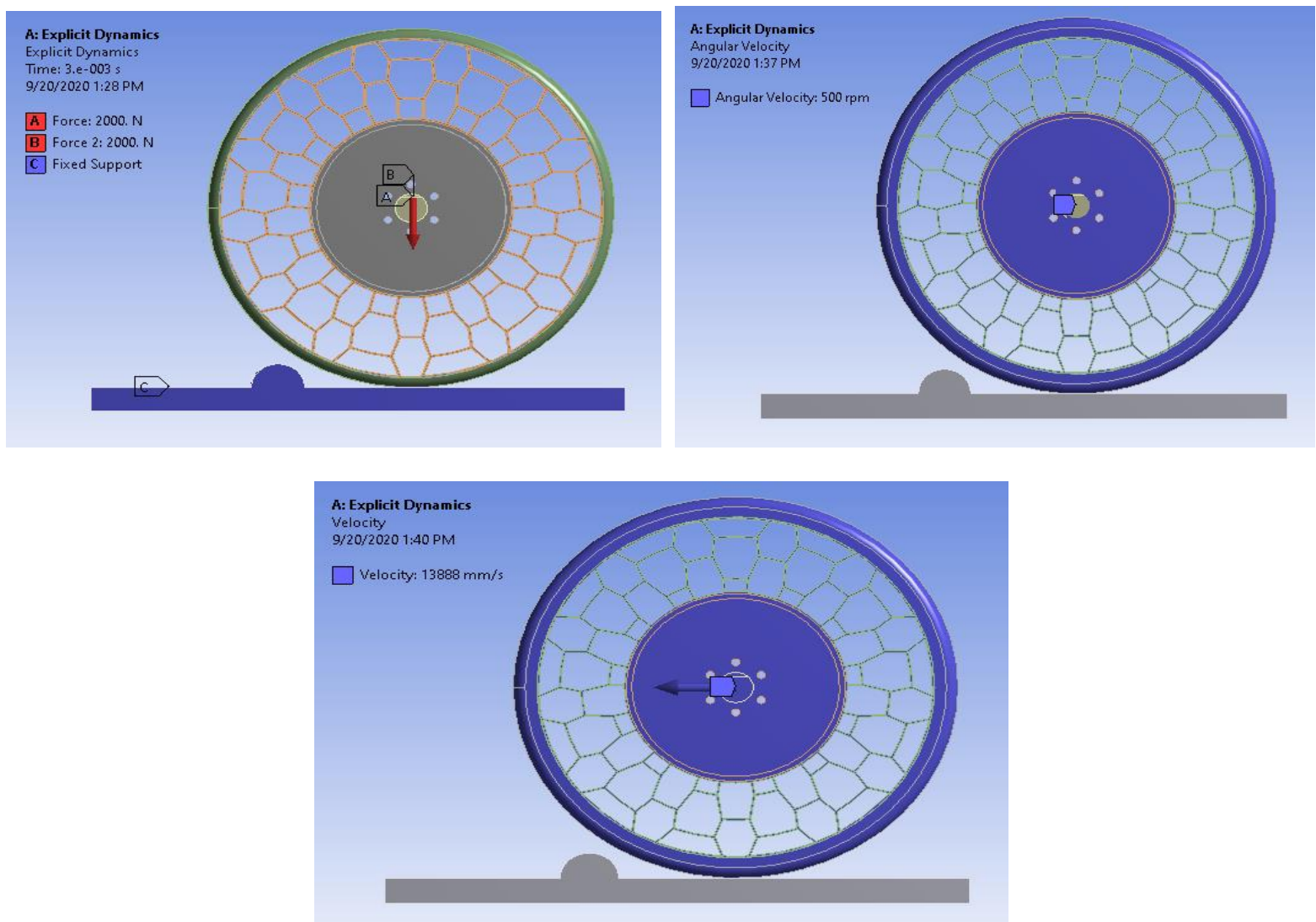

Gambar 3. Boundary Condition pada kondisi Dinamik 


\section{HASIL DAN PEMBAHASAN}

Dari simulasi yang telah dilaksanakan baik simulasi statis maupun dinamik didapatkan hasil berupa respons yaitu besarnya direct deformation dan equivalent stress pada kondisi statis maupun dinamik. Data response yang didapatkan selanjutnya dimasukkan kedalam matriks desain RSM seperti yang ditunjukkan pada table 5.

Tabel 5. Matriks Desain serta Respons Statis dan Dinamik

\begin{tabular}{ccccccccc}
\hline $\begin{array}{c}\text { Model } \\
\text { Experiment }\end{array}$ & $\begin{array}{c}\text { Tebal } \\
\text { Tapak }\end{array}$ & $\begin{array}{c}\text { Tebal } \\
\text { Spokes }\end{array}$ & $\begin{array}{c}\text { Tebal } \\
\text { Outerface }\end{array}$ & $\begin{array}{c}\text { Jumlah } \\
\text { Lubang }\end{array}$ & $\begin{array}{c}\text { Deformasi } \\
\text { Statis } \\
(\mathbf{m m})\end{array}$ & $\begin{array}{c}\text { Stress } \\
\text { Statis } \\
(\mathbf{M p a})\end{array}$ & $\begin{array}{c}\text { Deformasi } \\
\text { Dinamik } \\
(\mathbf{m m})\end{array}$ & $\begin{array}{c}\text { Stress } \\
\text { Dinamik } \\
(\mathbf{M P a})\end{array}$ \\
\hline Model 1 & 0 & 0 & 0 & 0 & 23.526 & 853.820 & 119.740 & 280.900 \\
Model 2 & -1 & 0 & 0 & 1 & 29.519 & 937.990 & 118.960 & 258.810 \\
Model 3 & 0 & -1 & -1 & 0 & 21.643 & 700.360 & 120.120 & 964.170 \\
Model 4 & -1 & 0 & 0 & -1 & 34.329 & 792.520 & 119.840 & 210.770 \\
Model 5 & 0 & -1 & 0 & 1 & 19.205 & 757.450 & 119.240 & 234.120 \\
Model 6 & 1 & 0 & 0 & -1 & 22.090 & 404.860 & 120.330 & 547.240 \\
Model 7 & 0 & 0 & 0 & 0 & 23.526 & 853.820 & 119.740 & 280.490 \\
Model 8 & 0 & 1 & -1 & 0 & 14.139 & 600.050 & 119.480 & 819.590 \\
Model 9 & -1 & 0 & -1 & 0 & 32.219 & 1.050 .100 & 120.070 & 549.160 \\
Model 10 & 1 & 0 & -1 & 0 & 21.110 & 228.940 & 120.250 & 281.500 \\
Model 11 & 0 & -1 & 0 & -1 & 73.940 & 1.686 .400 & 119.100 & 474.020 \\
Model 12 & 1 & 0 & 1 & 0 & 19.055 & 349.650 & 120.180 & 598.320 \\
Model 13 & 0 & -1 & 1 & 0 & 19.611 & 504.680 & 118.980 & 407.060 \\
Model 14 & -1 & -1 & 0 & 0 & 26.730 & 770.100 & 119.350 & 248.910 \\
Model 15 & 0 & 0 & -1 & 1 & 24.035 & 952.190 & 119.650 & 412.040 \\
Model 16 & 0 & 1 & 0 & -1 & 14.410 & 536.510 & 120.450 & 265.320 \\
Model 17 & 1 & -1 & 0 & 0 & 18.020 & 262.800 & 119.860 & 244.580 \\
Model 18 & 0 & 0 & 1 & 1 & 19.872 & 624.120 & 119.440 & 229.470 \\
Model 19 & -1 & 1 & 0 & 0 & 26.730 & 770.100 & 120.120 & 368.490 \\
Model 20 & 0 & 0 & 0 & 0 & 23.526 & 853.820 & 119.740 & 280.490 \\
Model 21 & 1 & 0 & 0 & 1 & 17.701 & 464.160 & 118.930 & 384.680 \\
Model 22 & -1 & 0 & 1 & 0 & 27.402 & 684.990 & 119.680 & 274.550 \\
Model 23 & 0 & 0 & -1 & -1 & 29.344 & 927.350 & 120.320 & 872.500 \\
Model 24 & 0 & 1 & 1 & 0 & 12.665 & 371.620 & 119.750 & 228.330 \\
Model 25 & 0 & 0 & 1 & -1 & 19.872 & 624.120 & 119.440 & 229.470 \\
Model 26 & 0 & 1 & 0 & 1 & 12.133 & 545.270 & 119.180 & 291.140 \\
Model 27 & 1 & 1 & 0 & 0 & 19.932 & 309.870 & 119.810 & 223.970 \\
\hline & & & & & & & &
\end{tabular}




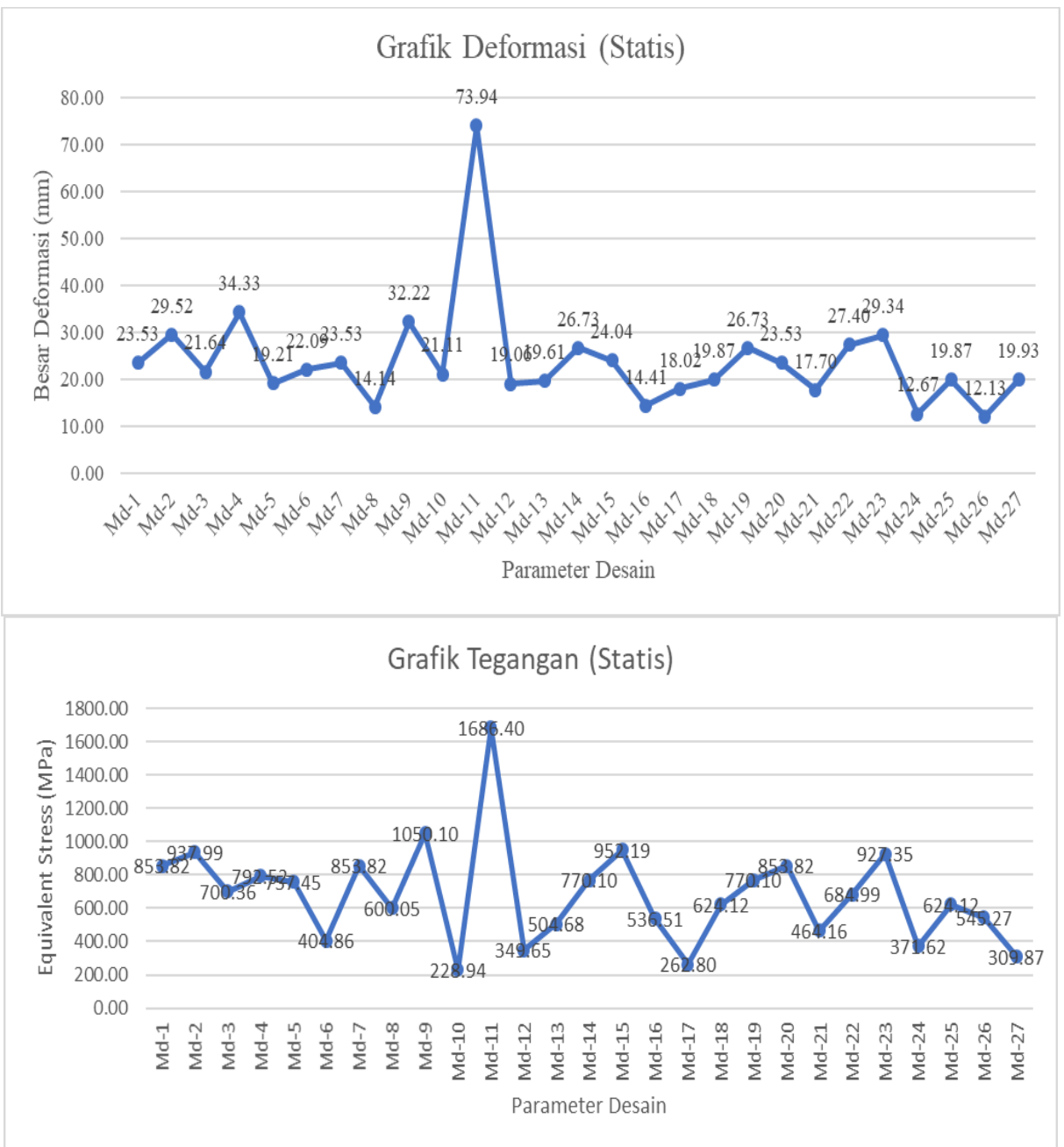

Gambar 4. Grafik Hasil Simulasi Statis
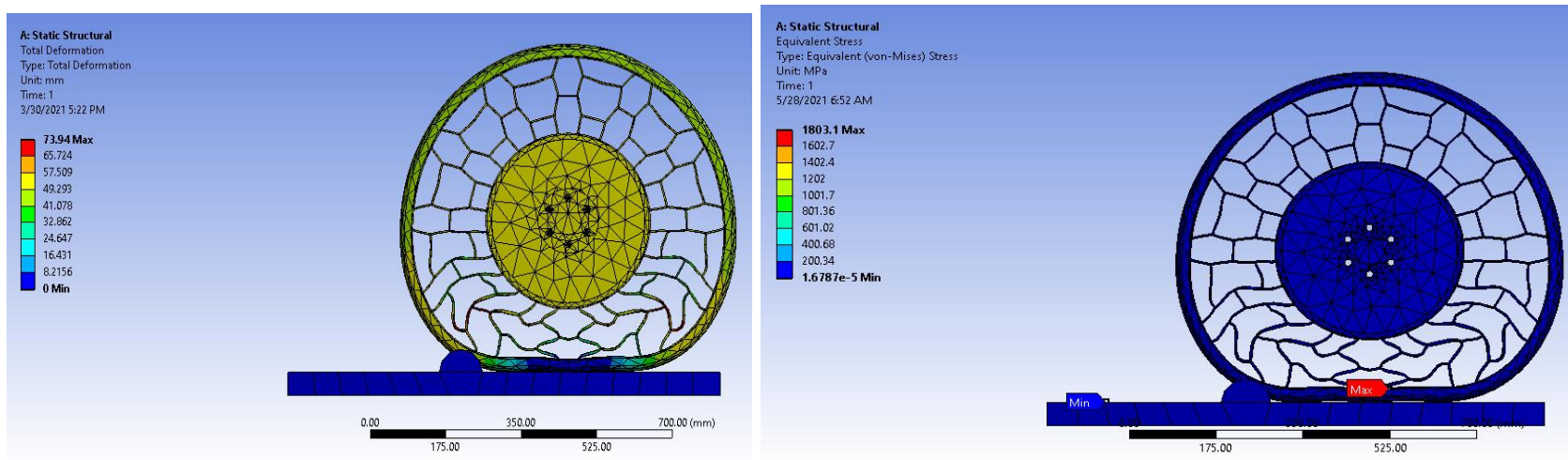

Gambar 5. Pola Deformasi dan Equivalent Stress Terbesar pada Kondisi Statis 


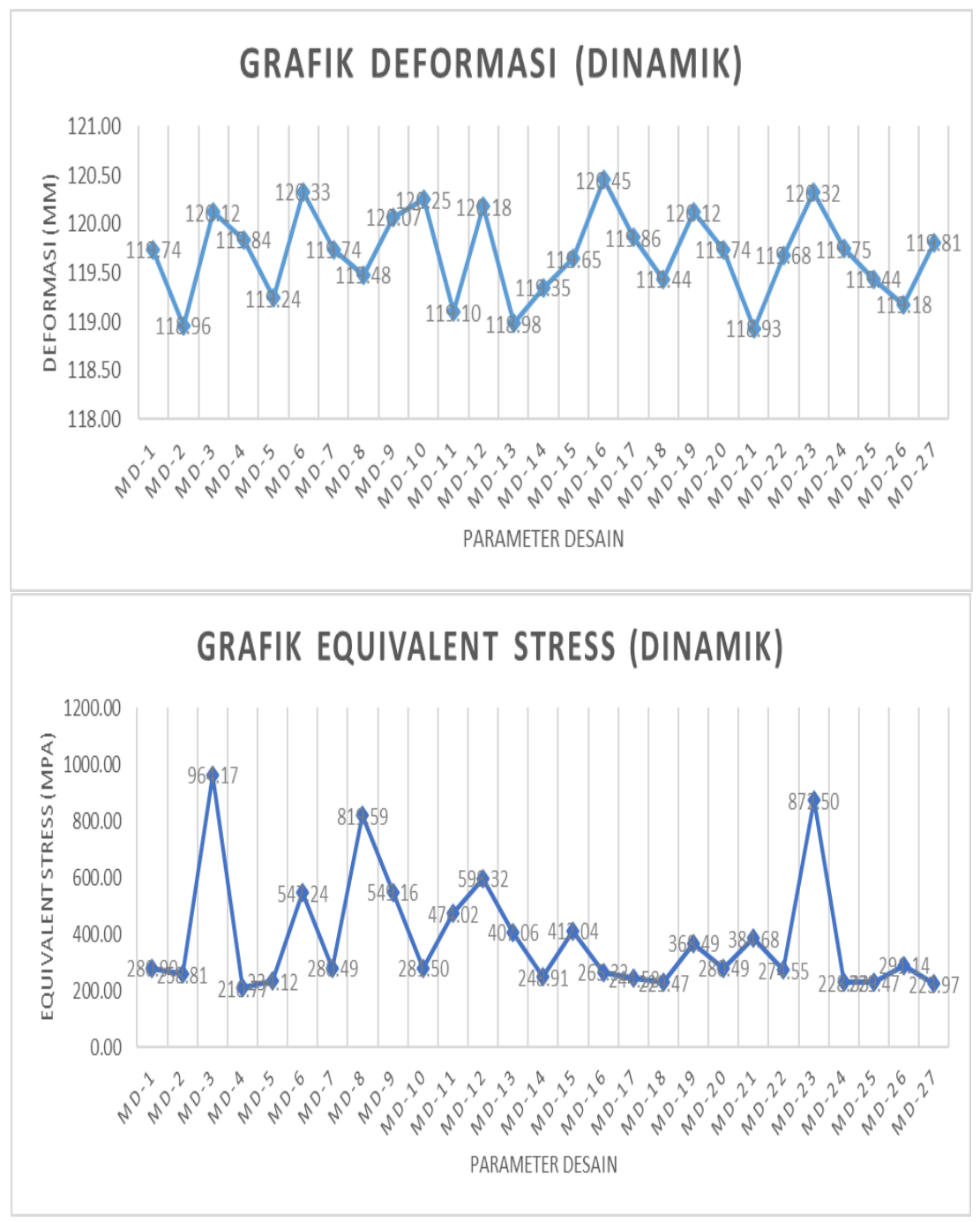

Gambar 6. Grafik Hasil Simulasi Dinamis 

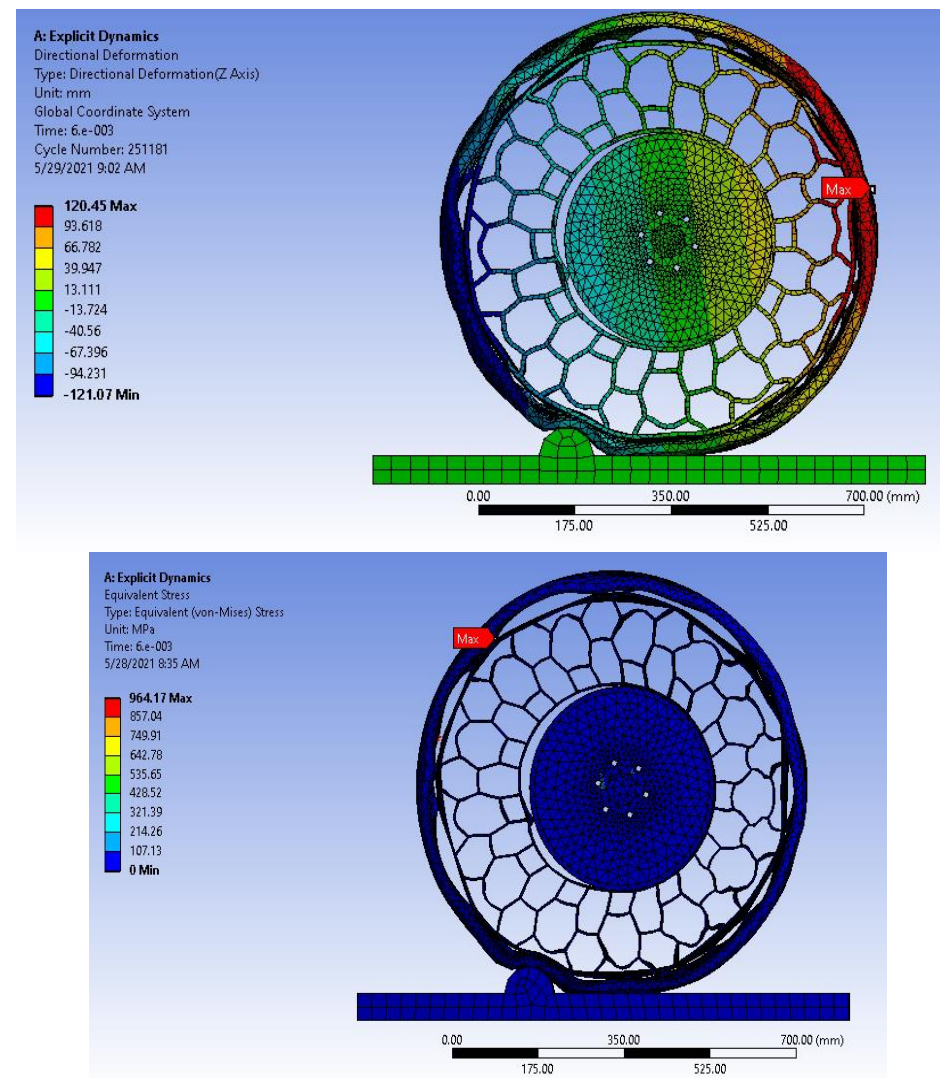

Gambar 7. Pola Deformasi dan Equivalent Stress Terbesar pada Kondisi Dinamis

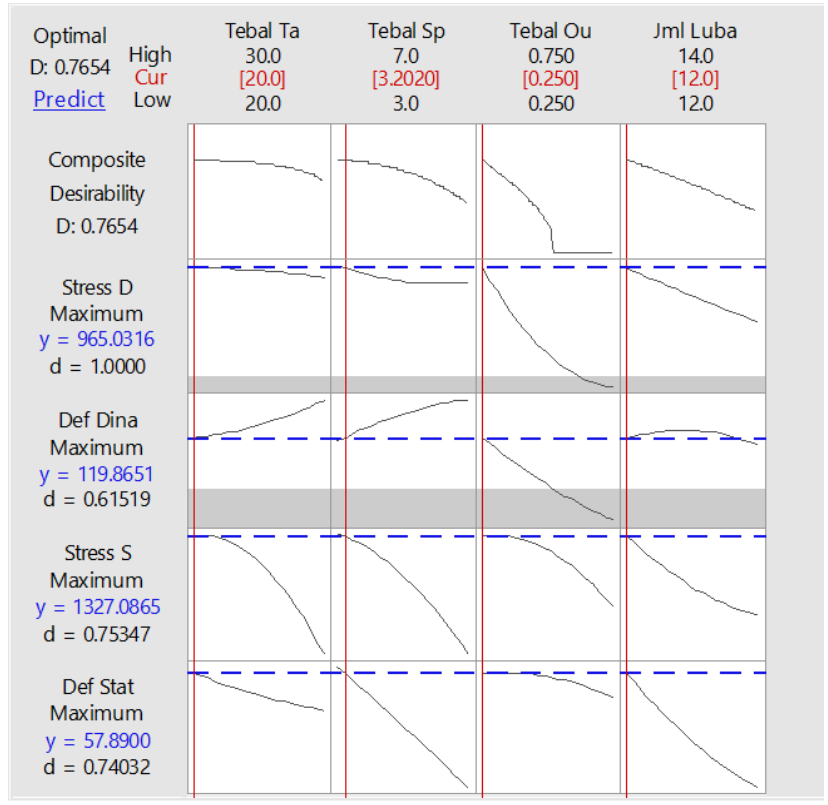

Gambar 8. Data Hasil Optimasi Desain dengan RSM Minitab 


\section{KESIMPULAN}

Berdasarkan hasil simulasi dan Response Surface Minitab didapatkan desain paling optimal pada parameter desain roda tanpa udara adalah tebal tapak $20 \mathrm{~mm}$, tebal spokes 3,2020 mm, tebal outerring 0,25 mm, dan jumlah lubang spokes 12 buah.

\section{UCAPAN TERIMA KASIH}

Kami mengucapkan banyak terimaksih kepada panitia SENATEK 2021 Fakultas Teknik, Universitas Muhammadiyah Purwokerto yang telah menfasilitasi terselenggaranya seminar nasional ini, semoga ini semua dapat bermanfaat bagi perkembangan teknologi khususnya dibidang Teknik mesin kedepannya.

\section{DAFTAR PUSTAKA}

Cho JR, Kim KW, Yoo WS, Hong SI. Mesh Generation Considering Detailed Tread Blocks for Reliable 3D Tire Analysis. Adv Eng Softw 2004; 35:105-13.

Rhyne T, Cron SM. Development of a non-pneumatic wheel. Tire Sci Technology 2006; 34:150-69.

Gibson LJ, Ashby MF. Cellular solids: structure and properties. Cambridge: Cambridge University Press; 1999.

Lu GX, Yu TY. Energy absorption of structures and materials. Cambridge: Woodhead Publishing Ltd; 2003.

Sun YT, Wang B, Pugno N, Wang B, Ding Q. In-plane stiffness of the anisotropic multifunctional hierarchical honeycombs. Compos Struct 2015; 131:616-24.

Li YM, Abbès F, Hoang MP, Abbès B, Guo YQ. Analytical homogenization for in-plane shear, torsion and transverse shear of honeycomb core with skin and thickness effects. Compos Struct 2016; 140:453-62.

Zhang QC, Yang XH, Li P, Huang GY, Feng SS, Shen C, et al. Bioinspired engineering of honeycomb structure - Using nature to inspire human innovation. Prog Mater Sci 2015; 74:332-400.

Ju J, Ananthasayanam B, Summers JD, Joseph P. Design of cellular shear bands of a non-pneumatic tireinvestigation of contact pressure. SAE Int J Pass Cars 2010; 3:598-606.

Kim K, Ju J, Kim D. Static contact behaviors of a non-pneumatic tire with hexagonal lattice spokes. SAE Int J Passeng Cars - Mech Syst 2013;6(3):1518-27.

Ju J, Kim DM, Kim K. Flexible cellular solid spokes of a non-pneumatic tire. Compos Struct 2012; 94:2285-95.

Gasmi A, Joseph PF, Rhyne TB, Cron SM. Development of a two-dimensional model of a compliant nonpneumatic tire. Int J Solids Struct 2012; 49:1723-40.

Ma JF, Summers JD, Joseph PF. Numerical investigation of effect of membrane thickness on the performance of cellular shear band based non-pneumatic tire. In: Proceedings of the ASME 2011 international design engineering technical conferences \& computers and information in engineering conference, Washington, DC, USA; 2011. 